一論 文—

(日本化学会誌, 1983, (1), p. $1 \sim 5$ )

(C) 1983 The Chemical Society of Japan

\title{
含水酸化チタン(IV)の結晶構造および細孔構造におよぼす 沈殿生成時における尿素添加の影響1)
}

\author{
（1982 年 6 月 16 日受理）
}

\author{
大井健太*北村孝雄 - 加藤俊作 - 菅坡和彦
}

\begin{abstract}
尿素添加㧊よび未添加の塩化チタン $(\mathbb{N})$ 溶液を加熱加水分解し, 沈殿生成時および熟成過程での沈殿 の結晶構造および細孔構造の変化を比較検討した。塩化チタン $(\mathbb{N})$ の加水分解速度は尿素添加の場合も 未添加の場合も棌ぼ等しく，尿素の加水分解速度にくらべてきわめて速かった。尿素添加により沈殿時 および熟成時に打いて，沈殿のアナタース形からルチル形への変化が抑制された。また，熟成時に拈け る細孔構造の变化が, 尿素添加により小さくなった。尿素未添加の場合, 加熱温度が $80^{\circ} \mathrm{C}$ から $100^{\circ} \mathrm{C}$ になると，沈殿の結晶子径は約 2.5 倍に増加した。これに対し尿素を添加した場合，加熱温度の影響は 尿素末添加の場合より小さかった。以上から，尿素添加の効果は，ルチル構造の形成を抑制すること， および細孔構造を安定化することにあると考学らる。
\end{abstract}

\section{1 緒言}

含水酸化チタン $(\mathbb{N})$ は無機イオン交換体として, あるいは触媒 用原料として重要である。含水酸チタン $(\mathbb{N})$ の調製法の一つとし て, 重量分析の一手段である均一沈殿法を参考にし, 尿素を添加 したチタン $(\mathbb{N})$ 塩溶液を加熱加水分解する方法が試みられている (以下，尿素法と呼ぶ)。尿素法で調製した含水酸化チタン $(\mathbb{N})$ は 高いウラン吸着能を示し ${ }^{2)}$ ，また従来の方法で調製した含水酸化 チタン (IV)よりも熱安定性が高い3)。これらの結果は, 尿素法で 調製した含水酸化チタン(N)が特異な物理化学的特性をもってい ることを示唆するが，含水酸化チタン(N)の構造形成におよぽす 尿素の役割は十分明らかでない。

本研究シリーズは，尿素法で含水酸化チタン(N)を調製するさ いの尿素の役割を明らかにし，さらに尿素法で調製した含水酸化 チタン ( IN)の調製条件とその物理化学的性質との関係を明確にす ることを目的にしている。本報告では，尿素添加および未添加の 塩化チタン $(N)$ 溶液を加熱加水分解し, 沈殿生成時および熟成過 程での沈殿の結晶構造・細孔棈造の変化を比較検討した。尿素添 加と未添加の場合の構造の違いから，含水酸化チタン(N)を調製 するさいの尿素の役割を考察した。

\section{2 実験}

\section{1 塩化チタン(IV)溶液の加水分解}

塩化チタン $(\mathrm{N})$ に冷水を加え $3 \mathrm{~mol} \cdot \mathrm{dm}^{-3}$ 塩化チタン $(\mathbb{N})$ 溶 液を調製し、ストック溶液とした。このストック溶液を加熱直前

四国工業技術試験所化学部, 761 高松市花の宮町

1）この報文を“尿素法で調集した含水酸化チタンの物理化学 的性質 (第 1 報)”とする.

2) 尾方 界, 海水誌, 24, 197(1971).

3）鉿木秀行, 岩井孝夫, 長谷川敏夫, 奥鼻邦雄, 掘江忠一, 香山 勲, 日化, 1977, 1063.
に希釈して $1 \mathrm{~mol} \cdot \mathrm{dm}^{-3}$ 塩化チタン(N)溶液 $\left(1 \mathrm{dm}^{3}\right)$ を調製し， 尿素を $2 \mathrm{~mol} \cdot \mathrm{dm}^{-8}$ となるよう添加したのち, $80^{\circ} \mathrm{C}$ あるいは 100 ${ }^{\circ} \mathrm{C}$ で加熱還流しながらかきまぜた。所定時間ごとに $20 \mathrm{~cm}^{3}$ の溶

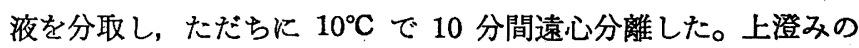
チタン濃度を原子吸光法で測定し塩化チタン(N)の加水分解率を 求めた。一方, 遠心分離した沈殿は蒸留水で洗浄し風乾した。ま た，尿素末添加の $1 \mathrm{~mol} \cdot \mathrm{dm}^{-3}$ 塩化チタン(N)溶液についても同 様の操作を行なった（以下，加熱法と呼ぶ)。

\section{2 沈殿の物理化学的性質の測定}

沈殷の結晶構造は, 理学電機(株)社製 D $3 \mathrm{~F}$ 型 X線回折装置を 用いて測定した。試料の粒子形態は日本電子(株)社製 JEM 7 型 透過電子顕微鏡を用いて観察した。表面積・細孔容積・細孔分布 は Carloerba 社製 Sorptomatic 1800 を用い, 窒素吸脱着等温 線から求めた。表面積は吸着等温線から BET 法で求めた。細孔 容積は飽和蒸気圧下での窒素吸着量から求め, 細孔分布は脱着等 温線から Wheeler の方法で求めた4)。

\section{3 塩酸溶液中での尿素の加水分解速度}

$4 \mathrm{~mol} \cdot \mathrm{dm}^{-3}$ 塩酸溶液 $\left(1 \mathrm{dm}^{3}\right)$ に尿素を $2 \mathrm{~mol} \cdot \mathrm{dm}^{-3}$ となるよ ら添加し， $80^{\circ} \mathrm{C}$ あるいは $100^{\circ} \mathrm{C}$ に加熱しながらかきまぜた。所 定時間ごとに $20 \mathrm{~cm}^{3}$ の溶液を分取し，ただらに $0^{\circ} \mathrm{C}$ 以下にして 保存した。尿素の加水分解は（1）式のように進むので，生成した アンモニアの濃度をカリボール法で求め ${ }^{5)}$, 尿素の加水分解率を 計算した。

$$
\mathrm{CO}\left(\mathrm{NH}_{2}\right)_{2}+\mathrm{H}_{2} \mathrm{O} \longrightarrow \mathrm{CO}_{2}+2 \mathrm{NH}_{3}
$$

4) A. Wheeler, "Catalysis Vol.II", Reinhold Publishing Coop. (1955) Chap. 2 ; 鹿伊富長, “吸着”, 共立全書 (1965) p. 118.

5）上野景平，斎藤幹彦，玉奥克已，分析化学， 18, 264 (1969). 


\section{3 結 果 亡考察}

\section{$3.180^{\circ} \mathrm{C}$ での塩化チタン(IV)の加水分解速度}

塩化チタン $(\mathbb{N})$ の加水分解率の経時変化找よび溶液の $\mathrm{pH}$ 変化 を図 1-(A) に示した。塩化チタン (N) の加水分解速度は加熱法 と尿素法で差異はなく，加熱 1 時間で $85 \%$ ，2 時間で $95 \%$ の于 タンが沈殷した。舟木らは，塩化チタン(N)の加水分解速度を種 々の温度で測定しているが ${ }^{6)}$, 今回の塩化チタン(N) の加水分解 速度は舟木らの結果とよく一致している。一方, 溶液の $\mathrm{pH}$ は 7 時間後までほとんど変化せず 1 以下であった。図 1-(B)に，4 $\mathrm{mol} \cdot \mathrm{dm}^{-3}$ 塩酸溶液中での尿素の加水分解速度を示した。尿素の 加水分解率は加熱時間とともにほぼ直線的に增加した。しかしな がら，加水分解速度はきわめて遅く，6時間加熱後でも加水分解 率は $5 \%$ 以下であった。すなわち，尿素法において溶夜の $\mathrm{pH} か ゙$ 加熱 7 時間後でも上昇しないのは，溶夜内の酸を中和するのに必 要なアンモニアが不足しているためである。

\section{2 沈殿の物理化学的性質}

図 2 は， $80^{\circ} \mathrm{C}$ でそれぞれ 1 時間，3時間，7時間加熱後の沈殿 のX線回折バターンを示したものである。加熱法の場合, 加熱 1 時間後の沈殿はアナタース構造 (ASTM No. 21-1272) とルチル 構造 (ASTM No. 21-1276) の混ざった回折パターンを示した。 その後, 加熱時間が長くなるにつれてルチル構造に対応する回折 ピークが高くなり，アナタース構造に対応する回折ピークが低く なった。加熱 1 時間後にほとんどのチタンが沈殿していること， また $80^{\circ} \mathrm{C}$ では固相反応による結晶の枟移が起こらないと考兄ら れることから，このよらなアナタース形からルチル形含水酸化チ タン(IV)への変化は沈殿の溶解析出により進むと考えられる。一 方, 尿素法の場合, 1 時間加熱後の沈䟝はアナタース構造に対応 する回折パターンを示した。アナタース構造に対応するピークの

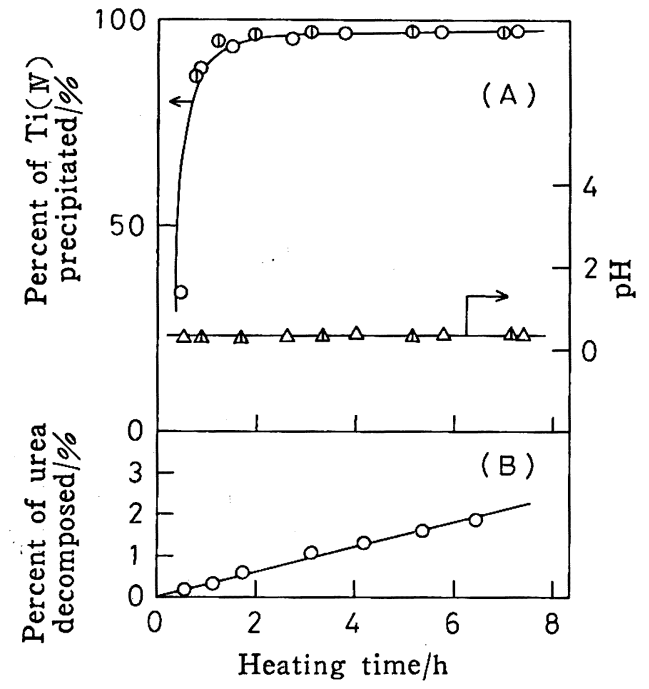

Fig. 1 Rate of the precipitation of $\mathrm{Ti}(\mathbb{V})$ and $\mathrm{pH}$ change during hydrolysis: (A), and the decomposition rate of urea in $4 \mathrm{~mol} \cdot \mathrm{dm}^{-3} \mathrm{HCl}$ solution: (B)

Tempetature : $80^{\circ} \mathrm{C}$

$\bigcirc, \triangle:$ In the absence of urea

(1), $\triangle:$ In the presence of urea

6）舟木好右衛門，佐伯雄造，工化，59，1291(1956).

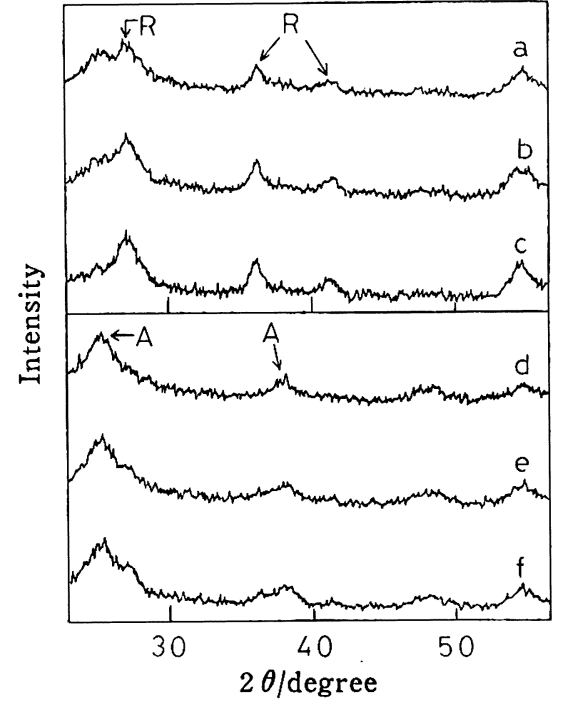

Fig. 2 X-ray diffraction patterns of the precipitate

$$
\begin{aligned}
& \text { Hydrolysis temperature }: 80^{\circ} \mathrm{C} \\
& \text { a : No urea, } 1 \text { hour heating } \\
& \text { b : No urea, } 3 \text { hours heating } \\
& \text { c : No urea, } 7 \text { hours heating } \\
& \text { d : With urea, } 1 \text { hour heating } \\
& \text { e : With urea, } 3 \text { hours heating } \\
& \text { f : With urea, } 7 \text { hours heating }
\end{aligned}
$$

回折強度は 7 時間加熱後の沈殿においてもほとんど変わらなかっ た。7 時間加熱後の沈䟝には，また，ルチル構造に対応する回折 ピークがわずかに現われた。尿素法と加熱法で調製した沈殷の結 晶構造の違いから，尿素は沈䟝生成および熟成の各段階でルチル 構造の形成を強く妨げていると推論される。

図 3 は，それぞれ 1 時間および 7 時間加熱後の沈弫の電子顕微 鏡写真である。加熱法の場合，加熱初期の沈股は微粒子からなる が，熟成が進むにつれて針状の粒子が增加した。これは，微粒子 が熟成により針状のルチル形含水酸化チタン $(\mathbb{N})$ に変化している ことを示している。一方，尿素法の場合，加熱初期の沈䟝も熟成 後の沈殿も微粒子の集合体からなり，沈殿生成時の粒子形態が熟 成後もたもたれていることがわかっだ。

表 1 に，それぞれ 1 時間， 3 時間， 7 時間後の沈股の表面積・ 細孔容積・平均細孔径を示した。図 4 は沈殿の細孔分布曲線を示 したものである。加熱法の場合, 沈殿の比表面積は沈殿生成㭙の むのでも熟成後の沈殿でもほとんど变わらないが，細孔容積は熟 成が進むにつれて減少した。熟成による細孔容積の減少は半径 $50 \AA(1 \AA=0.1 \mathrm{~nm})$ 付近の細孔が少なくなったことと対応して いる。一方，尿素法の場合，加熱初期の段階で加熱法の沈晦の約 1.5 倍の表面皘および細孔容積をもつ沈殿が生成した。その後熟 成が進むにつれて表面積はわずかに大きくなったが，平均細孔径 はほとんど変わらなかった。細孔分布曲線も熟成時間に無関係に 類似した曲線となった。

ところで, 微結晶性試料の細孔構造は微結晶の粒子形態および それらの凝集状態により決まる。加熱法でみられたような熟成に 上る細孔容積の減少は，針状のルチル形含水酸化チタン $(\mathbb{N})$ 将生 成し品隙構造が変化したためと考えることができる。一方，尿 素法では，沈䟝の細孔分布は熟成によりほとんど変化しなかっ た。すなわち，尿素が共存する場合には，沈股の結晶構造のみな 
a

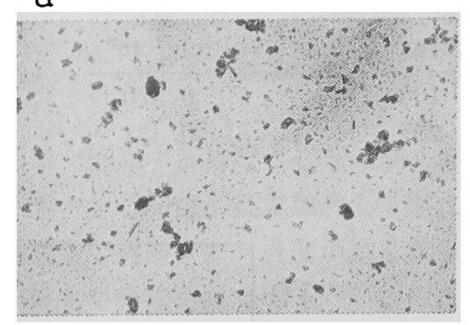

d

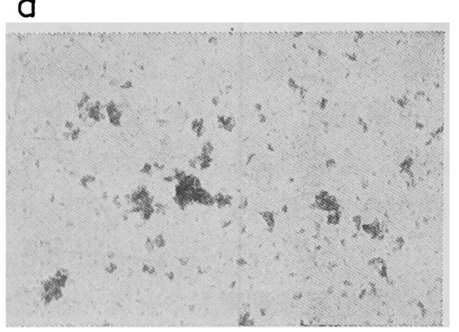

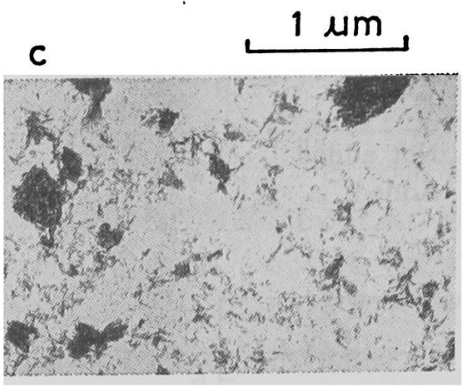

f

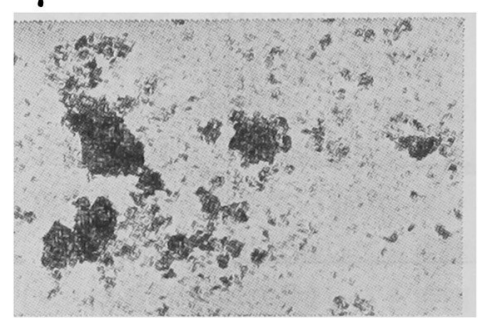

Fig. 3 Electronmicrographs of the precipitates

The symbols are the same as those in Fig. 2.

Table 1 Surface properties of the precipitates obtained at $80^{\circ} \mathrm{C}$

\begin{tabular}{clcccc}
$\begin{array}{c}\text { Sample } \\
\text { No. }\end{array}$ & Urea & $\begin{array}{c}\text { Heating } \\
\text { time } / \mathrm{h}\end{array}$ & $\begin{array}{c}\text { Specific surface } \\
\text { area } / \mathrm{m}^{2} \cdot \mathrm{g}^{-1}\end{array}$ & $\begin{array}{c}\text { Pore } \\
\text { volume } / \mathrm{cm}^{3} \cdot \mathrm{g}^{-1}\end{array}$ & $\begin{array}{c}\text { Mean pore } \\
\text { radius } / \AA\end{array}$ \\
\hline 1 & Not added & 1 & 122 & 0.212 & 34.8 \\
2 & Not added & 3 & 128 & 0.171 & 26.8 \\
3 & Not added & 7 & 122 & 0.136 & 22.3 \\
4 & Added & 1 & 198 & 0.319 & 32.3 \\
5 & Added & 3 & 235 & 0.372 & 31.6 \\
6 & Added & 7 & 243 & 0.362 & 29.8
\end{tabular}

らず粒子の凝集状態も熟成の影響をほとんど受けないと考えられ る。Harris らは, チタンテトラブトキシドから調製した含水酸 化チタン $(\mathrm{N})$ を水溶液中で還流した場合その細孔容積が増加する と報告している7)。したがって，今回のように細孔構造が熟成後 も変化しないのは尿素添加の効果と考えることができる。

\section{$3.3100^{\circ} \mathrm{C}$ における塩化チタン(IV)の加水分解}

$100^{\circ} \mathrm{C}$ における塩化チタン (N) の加水分解速度を図 5 に示し た。 $80^{\circ} \mathrm{C}$ で加熱した場合と同様に，加水分解速度は加熱法と尿 素法でほとんど差がなく 1 時間で $90 \%$ 以上のチタンが沈殿した。 溶液の $\mathrm{pH}$ は加熱法と尿素法で異なった挙動を示した。加熱法の 場合，加熱時間が増しても $\mathrm{pH}$ は 1 以下であったが，尿素法の場 合, 加熱 6 時間後に $\mathrm{pH}$ は上昇し始め 8 時間後には 5 となった。 尿素の加水分解速度を図 5-(B) に示した。尿素の分解速度は 80 ${ }^{\circ} \mathrm{C}$ で加熱した昜合よりもかなり速く，6 時間後には $50 \%$ の尿素 が分解した。尿素法における $\mathrm{pH}$ の上昇は，遊離の酸がアンモニ アにより中和されたためである。

\section{4 沈殿の物理化学的性質}

7 洔間加熱後の沈殿の X線回折パターンを図 6 に示した。 $80^{\circ} \mathrm{C}$ の場合と同様に, 加熱法の沈殷はルチル構造に対応する回折パタ ーンを示し尿素法の沈殿はアナタース構造に対応する回折パター ンを示した。ただし， $100^{\circ} \mathrm{C} て ゙$ 生じた沈殿の回折ピークは $80^{\circ} \mathrm{C}$ の場合より鋭くなっており,より大きな結晶粒が生成している

7) M. R. Harris, G. Whitaker, J. Appl. Chem., 13, 348 (1963).

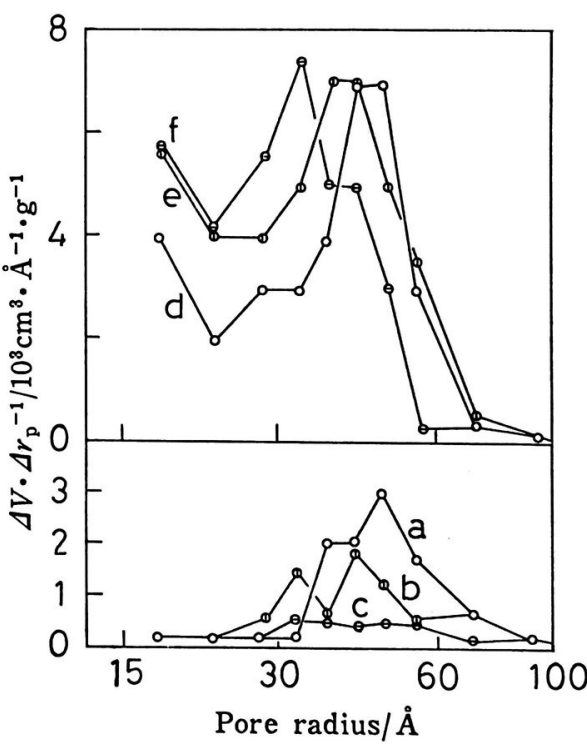

Fig. 4 Pore volume distribution curves of the precipitates prepared at $80^{\circ} \mathrm{C}$

The symbols are the same as those in Fig. 2.

ことを示している。加熱法の場合，（110）回折線の半值幅から Scherrer の式息を用いて結晶子径を計算すると $80^{\circ} \mathrm{C}$ では $40 \AA$ と

8) H. P. Klug, L. E. Alexander, "X-ray Diffraction Procedure for Polycrystalline and Amorphous Materials", John Wiley and Sons (1956) p. 491. 
Table 2 Surface properties of the precipitates obtained at $100^{\circ} \mathrm{C}$

\begin{tabular}{clcccc}
$\begin{array}{c}\text { Sample } \\
\text { No. }\end{array}$ & Urea & $\begin{array}{c}\text { Heating } \\
\text { time } / \mathrm{h}\end{array}$ & $\begin{array}{c}\text { Specific surface } \\
\text { area } / \mathrm{m}^{2} \cdot \mathrm{g}^{-1}\end{array}$ & $\begin{array}{c}\text { Pore } \\
\text { volume } / \mathrm{cm}^{3} \cdot \mathrm{g}^{-1}\end{array}$ & $\begin{array}{c}\text { Mean Pore } \\
\text { radius } / \AA\end{array}$ \\
\hline 1 & Not added & 7 & 100 & 0.370 & 74.0 \\
2 & Added & 7 & 237 & 0.431 & 36.4
\end{tabular}

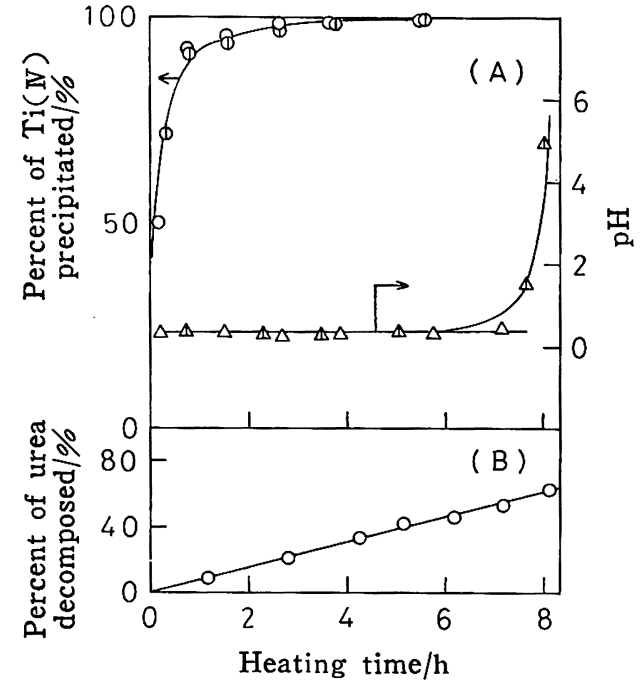

Fig. 5 Rate of the precipitation of $\mathrm{Ti}(\mathbb{N})$ and $\mathrm{pH}$ change during hydrolysis : (A), and the decomposition rate of urea in $4 \mathrm{~mol} \cdot \mathrm{dm}^{-3} \mathrm{HCl}$ solution : (B)

Temperature : $100^{\circ} \mathrm{C}$

$\bigcirc, \triangle:$ In the absence of urea

(1) $\triangle:$ In the presence of urea

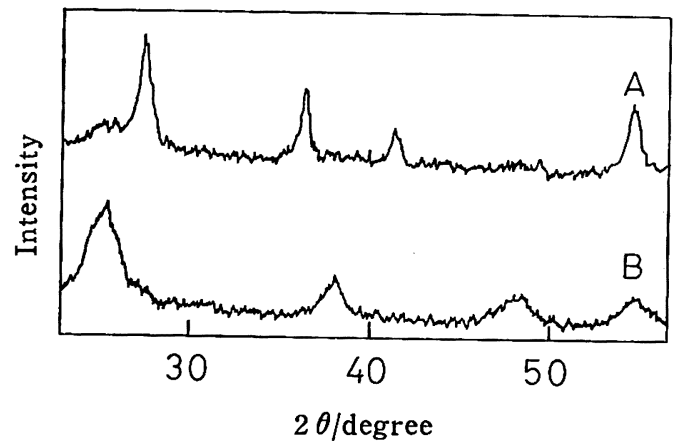

Fig. $6 \mathrm{X}$-ray diffraction patterns of the precipitates

Temperature : $100^{\circ} \mathrm{C}$

$A$ : No urea, 7 hours heating

B : With urea, 7 hours heating

なり $100^{\circ} \mathrm{C}$ では $102 \AA$ となり, 約 2.5 倍の結晶が生成している。

これは，高温になると沈股の溶解析出が進みやすくなるため結 晶粒が大きくなったと考えられる。一方，尿素法の場合，沈䟝の 結晶子径は $80^{\circ} \mathrm{C}$ で $29 \AA, 100^{\circ} \mathrm{C}$ で $43 \AA$ となり, 加熱法にくら べると加熱温度の影響は小さかった。

沈殿の表面積・細孔容積・平均細孔径を表 2 に示した。図 7 は 沈殿の細孔分布曲線を示したものである。図 7 には，また， $80^{\circ} \mathrm{C}$ で 7 時間加熱後の沈殿の細孔分布曲線を同時に示した。加熱法の 場合, $100^{\circ} \mathrm{C}$ で生じた沈明には半径 $20 \AA$ から $200 \AA$ の Mesopore が $80^{\circ} \mathrm{C}$ の場合よりも多数形成された。それにともない，

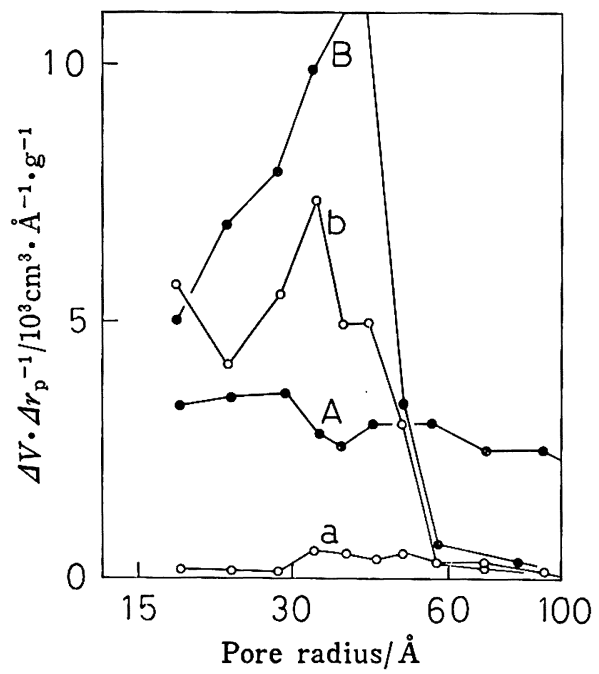

Fig. 7 Pore volume distribution curves of the precipitates after 7 hours heating

a : No urea, $80^{\circ} \mathrm{C}$

b : With urea, $80^{\circ} \mathrm{C}$

A : No urea, $100^{\circ} \mathrm{C}$

B : With urea, $100^{\circ} \mathrm{C}$

沈股の細孔容積は $80^{\circ} \mathrm{C}$ の場合の約 2.7 倍になった。 $100^{\circ} \mathrm{C} て ゙$ 加 水分解した場合，より大きな結晶粒が凝集しているので，その空 隍すなおち細孔が幅広くなり Mesopore が多数形成されたも のと推察される。一方, 尿素法の場合, 加水分解温度が $100^{\circ} \mathrm{C} に$ なると，沈尉の細孔容積は $80^{\circ} \mathrm{C}$ の場合の 1.2 倍ほどになったが， 細孔分布は両者ともよく似た曲線になった。以上から, 含水酸化 チタン (IN)の結晶構造および細孔構造は, 尿素添加により加熱温 度の影響をあまり受けなくなると考えられる。

\section{5 尿素の役割}

尿素法の特徽は以下のようにまとめられる。

（1）塩化チタン（N)の加水分解速度は尿素を添加しない場合 とほぼ等しく，尿素の加水分解速度にくらべてきわめて速い。

（2）尿素添加により，沈殿時および熟成時においてアナター ス形からルチル形への変化が抑制される。また，熟成時に括ける 細孔構造の変化が抑制される。

（3）加熱温度の影響は尿素未添加の場合ほど大きくない。

均一沈殿法の特徵は，溶液内で沈殿剂が徐々にしかも均一に発 生するため，ち密で共沈股が少なく沪過洗浄の容易な沈殷が得ら れることにある ${ }^{9)}$ 。今回の尿素法の場合，塩化チタン(N)の加水 分解速度は尿素未添加の場合とほぼ同じである。すなわち，塩化 チタン (N) 性素の分解によって生じたアンモニアにより沈殿す るのではなく，おもに熱的に加水分解すると考えられる。また， 沈殿の結晶棈造および細孔構造は尿装の加水分解速度が変化して もあまり変わらない。したがって，尿素法は，その方法は均一沈

9）日本化学会編, “实験化学講座 続 2”, 丸善 (1967) p. 159. 
殿法に類似しているが原理的には均一沈殿法と異なると考えるの が妥当である。尿素添加の効果は，むしろ上記 (2)にみられるよ らにルチル構造の形成を抑制すること，および細孔棈造を安定化 することにあるのたろう。

尿素と同様にルチル構造の形成を抑制する物質として硫酸イオ ンが知られている ${ }^{10) 11) 。 ま た, ~ チ タ ン ~}(\mathrm{~N})$ 塩溶液を加熱して酸化 チタン $(\mathbb{N})$ を調製する場合, 溶液中の硫酸イオン濃度が高くなる

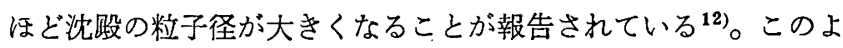
らな硫酸イオン添加による結晶構造あるいは粒子径の変化は, 硫 酸イオンがチタン (N)イオンの加水分解過程あるいは結晶成長過 程でチタン(N)イオンと強く相互作用するためと考えられてい る $^{10) 12)}$ 。硫酸イオンは，また，含水酸化チタン(N)の細孔構造に

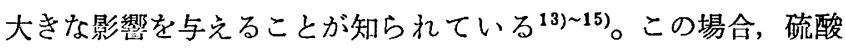
イオンが含水酸化チタン $(\mathrm{N})$ ゾル粒子にイオン交換吸着し細孔構 造を变化させると考えられている。

ところで，今回調製した含水酸化チタンの尿素吸着量を測定し た結果, ルチル形試料もアナタース形試料も水溶液あるいは 0.1 $\mathrm{mol} \cdot \mathrm{dm}^{-3}$ 塩酸溶液中で尿素をほとんど吸着しない $(0.01 \mathrm{meq} / \mathrm{g}$

10）舟木好右衛門，佐伯雄造，工化，59，1295(1956).

11）黒崎章人, 岡崎 進, 日化, 1976, 1816.

12) E. Matijevic, J. Colloid Interface Sci., 58, 374(1977).

13) S. J. Gregg, M. I. Pope, Kolloid. Z., 27, 174(1960).

14) J. P. Bonsack, J. Colloid Sci., 44, 430(1973).

15）牧 俊夫, 日化, 1978, 945 .
以下）ことがわかった。一方，硫酸イオンの場合， $\mathrm{pH} 2$ から 4 の範囲で含水酸化チタン $(\mathrm{N})$ に $0.2 \mathrm{meq} / \mathrm{g}$ 吸着されることが報 告されている ${ }^{16)}$ 。また，陰イオンである硫酸イオンと陽イオンで あるチタン(N)イオンとでは静電的にイオン対を生成しやすい が，弱塩基性物質である尿素の場合，酸性溶液中でチタン（N)イ オンと静電的にイオン対を生成する可能性は注とんどないと考え られる。したがって，尿素は，硫酸イオンの場合のようにチタン

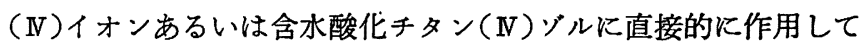
アナタース㯨造を安定にしているのではなく，むしろ他の機構に よりアナタース構造を安定化していると思われる。

尿素は, タンパク質の変性剤として知られている。尿素による タンパク質の変性は, 水の構造を破壊する尿素の作用と, タンパ ク質の極性基に対する尿素の直接的相互作用との双方が相まって

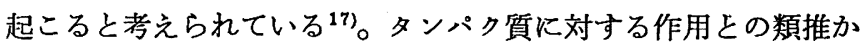
ら，今回の尿素法に批いても尿素が水の構造を変化させてアナタ 一ス構造を安定にしていると推測される。しかしながら，高温で かつ酸性領域での尿素水溶液の物理化学的性質については十分明 らかではない。尿素水溶液の物理化学的性質と含水酸化チタン の結晶構造あるいは細孔構造との関係については，今後の検討課 題としたい。

16）竹中安夫, 中谷宗䦜，杉森修一，内田広幸，日本化学会第 43 春季年会講演予稿集, p. 585(1981).

17）上平初穂，蛋白質・核酸・酵素，18，62(1973)。

\title{
The Influence of the Addition of Urea in the Precipitation of Hydrous Titanium(IV) Oxide on Its Crystal Structure and Pore Structure ${ }^{\dagger}$
}

\author{
Kenta Oor*, Takao Kitamura, Shunsaku Katoh \\ and Kazuhiko Sugasaka \\ Government Industrial Research Institute, Shikoku; \\ Hananomiya-cho, Takamatsu-shi 761 Japan
}

The effect of added urea on the crystal structure and pore structure of hydrous titanium( $\mathbb{N})$ oxide (HTiO) was investigated by X-ray diffractometry, electronmicroscopic observation, and $\mathrm{N}_{2}$ adsorption desorption at $-196^{\circ} \mathrm{C}$. $\mathrm{HTiO}$ was prepared by the thermal hydrolysis from titanium $(\mathbb{N})$ chloride solution with or without urea.

The rate of the precipitation of HTiO was not affected by the addition of urea. The precipitation rate was extremely high compared with the decomposition rate of urea. In the absence of urea, the precipitates obtained after an hour heating at $80^{\circ} \mathrm{C}$ was a mixture of rutile and anatase type, and had mesopores around $4 \mathrm{~nm}$ radius. The anatase type HTiO was gradually converted into rutile and the mesopores disappeared by the subsequent heating at $80^{\circ} \mathrm{C}$. In the presence of urea, anatase type $\mathrm{HTiO}$ with mesopores around $4 \mathrm{~nm}$ radius was obtained by an hour heating at $80^{\circ} \mathrm{C}$. Both the crystal structure and pore volume scarcely changed by the subsequent heating for 6 hours at $80^{\circ} \mathrm{C}$. When titanium( $\mathbb{N}$ ) chloride was hydrolyzed at high temperatures, HTiO with large crystallite size and pore volume was obtained. The influence of the hydrolysis temperature on the crystal structure and pore structure was not so remarkable in the presence of urea as in the absence of urea.

$\dagger$ Physicochemical Properties of Hydrous Titanium(N) Oxide Prepared by the Urea Method. I. 